\title{
PRELIMINARY RESULTS OF INVESTIGATIONS ON ARCTIC DRIFT STATION CHARLIE
}

by

WILLIAM J. CROMIE

LAMONT GEOLOGICAL OBSERVATORY

Columbia eantuersity

PALISADES. NEW YORK

Scientific Report No. 3

AF $19(604) 2030$

October 1960

Prepared for

Geophysics Research Directorate

Air Force Cambridge Research Laboratories

Air Force Research Division

Air Research and Development Command

United States Air Force

Bedford, Massachusetts 

AFCRC $-\mathrm{TN}-60-259$

PRELIMINARY RESULTS OF INVESTIGATIONS ON ARCTIC DRIFT STATION CHARLIE

by

William J。Cromie

LAMONT GEOLOGICAL OBSERVATORY

(Columbia University)

Palisades, New York

Scientific Report \#3

AF 19 (604) 2030

October, 1960

Prepared for

GEOPHYSICS RESEARCH DIRECTORATE AIR FORCE CAMBRIDGE RESEARCH LABORA TORIES

AIR FORCE RESEARCH DIVISION

AIR RESEARCH AND DEVELOPMENT COMMAND

UNITED STATES AIR FORCE

BEDFORD, MASSACHUSETTS 
Requests for additional copies by Agencies of the Department of Defense, their contractors, and other Government agencies should be directed to the:

ARMED SERVICES TECHNICAL INFORMATION AGENCY ARLINGTON HALL STATION

ARLINGTON 12, VIRGINIA

Department of Defense contractors must be established for ASTIA services or have their 'need-to-know' certified by the cognizant military agency of their project or contract.

All other persons and organizations should apply to the:

U. S. DEPARTMENT OF COM MERCE OFFICE OF TECHNICAL SERVICES

WASHINGTON 25, D. C. 
Abstract

Station Charlie, established on the pack ice of the Arctic

Basin, drifted in an east-west line across a shallow peninsula of

the Chukchi shelf during July-August, 1959. Continuous soundings were taken within an accuracy of one meter across the feature and in adjacent deep water. A bathymetric profile has been constructed and the angles of slope computed from seismic reflections.

Twenty-two piston cores were taken, ranging in penetration to $250 \mathrm{~cm}$. Over one hundred bottom photographs, made on the shelf and in deep water, show rocks and an abundance of life. Six trawls brought to the surface geological and biological specimens. An attempt at dating by radiocarbon analysis of pelagic forams is in process.

Besides investigations in submarine geology and biology, work in seismology and magnetics was done. Reflection techniques were used for determinations of dip and strike of bottom sediments. Studies were made of long range sound transmission by seismic means. Both relative and continuous absolute values of the magnetic field were measured. Records were taken during a magnetic storm and solar flare disturbance.

A vertical seismometer was installed on the pack ice and successfully recorded at least one earthquake. Small variations in atmospheric pressure were recorded continuously on a microvariobarograph.

$$
\text { ** * * * }
$$


Station Charlie was established in April 1959 to continue

Arctic Ocean research begun during the International Geophysical

Year. The undertaking, a combined military-civilian effort, was launched in conjunction with the International Geophysical Cooperation 1959. Investigations and data reported upon in this paper were conducted by personnel from Lamont Geological Observatory, Columbia University, under Contract AF 19 (604) 2030 to the Geophysics Research Directorate, Air Force Cambridge Research Center.

Charlie, originally designated Alpha II, was first established on the permanent pack ice of the Arctic Basin, approximately 250 nautical miles north-northwest of Point Barrow, Alaska. The floe chosen, a large one, measured seven by four and a half miles and averaged 10 to 12 feet in thickness. During the period covered by this paper ( June to October, 1959), the station drifted north (June-July) for ninety miles, then west (July-October) a distance of one-hundred-seventy miles (Fig。1)。 (Mileage figures are given in nautical miles. The se are straight line distances。)

The actual wind and current controlled track covered about twice the straight-line mileage (Fig。2). The floe drifted approximately 145 miles a month, or 4.5 miles per day. The average drift rate of station Alpha (June, 1957-November, 1958) was 3.5 miles per day (Hunkins, 1959). Charlie's average of 4.5 miles per day is for the summer season only, when the pack is looser and moves faster. Taking twelve-month 
averages, the drift rates of the two stations would probably be much closer。

During its northward drift the floe was probably in the western part of the anticyclonic current eddy north of Alaska (Worthington, 1953). Apparently, it broke out of this eddy after August $16\left(165^{\circ} \mathrm{W}\right)$ and travelled due west towards Siberia. After an essentially westward drift from August 16 to September 30, the floe turned south and east. This is in contrast to the clockwise pattern of ice drift experienced by other stations in that area $\left(77^{\circ} \mathrm{N}, 171^{\circ} \mathrm{W}\right) . \mathrm{N}, \mathrm{P}, 2, \mathrm{~T}-3$ and $\mathrm{T}-2$ all drifted north and west. The south and east track may be due to the south-eastward progression of an anticyclonic pressure system, prevailing in the Arctic Ocean from October to July (Browne, 1959).

Lamont Observatory scientists carried out a program in marine geophysics encompassing submarine geology, magnetics and seismology. Emphasis in this paper will be on the geologic investigations and preliminary results.

A new type precision depth recorder, developed at Lamont, formed the foundation of the submarine geology program. The instrument, in continuous operation since July 7 , records bottom depths to an accuracy of one meter. It does this with an acoustic energy of one watt, producing one ping per minute at an output frequency of $1.8 \mathrm{kc}$. One watt of energy has proved sufficient in depths of 1400 fathoms. 
The drift track took the station across a shallow peninsula of the Chukchi shelf, which is in line with the Bering Straits. The traverse was in an east-west line, providing an excellent opportunity to study this feature.

Charlie first passed over the eastern part of the peninsula on July 10 at latitude $77^{\circ} 39.5^{\prime} \mathrm{N}$, longitude $161^{\circ} 10.4^{\prime} \mathrm{W}$. On that day soundings decreased from 1028 fathoms to 330 fathoms in 18 hours. This is believed to have been a north or northeastward extending tongue of the elevation. The station passed over this extension and into 1460 fathoms of water. On July 13-14 Charlie drifted over the main portion of the feature into $288 \mathrm{fm}$ depths. Soundings decreased to $192 \mathrm{fms}$ on July 17 at $163^{\circ} 14^{\prime} \mathrm{W}$. The shallowest sounding occurred on July 22 at $77^{\circ} 43^{\prime} \mathrm{N}, 163^{\circ} 43^{\prime} \mathrm{W}$ where a depth of $138 \mathrm{fms}$ was recorded.

The floe remained over the peninsula until August 30, reaching the western slope at $77^{\circ} 57^{\prime} \mathrm{N}, 169^{\circ} 43^{\prime} \mathrm{W}$. Figure 4 shows a portion of the drift track from 29 August to 4 September together with the P.D.R. records for those days. Soundings went from $250 \mathrm{fms}$ to $1400 \mathrm{fms}$ during this time. The floe moved 28 miles in the four days with an average wind of 13 knots from the northeast.

The angle of slope of the Rise was obtained by seismic reflection. An "L" spread of 12 geophones yielded dip values for the water-sediment interface. Values for the western slope averaged $4.7^{\circ}$ from daily shots taken 28 August to 3 September. Maximum dip was 7.30 on 28 August. 
The dip azimuth averaged $272^{\circ}$. No explosives were available for seismic soundings on the east side.

The bathymetric profile (Fig。3) shows that the feature is unlike a typical submarine rise. Slope angles are much steeper $\left(2.8^{\circ}\right.$ to $\left.7.3^{\circ}\right)$ than usually encountered. Because of the shallow depths (138-250 fathoms), it is also unlike a seamount. It might better be called a Submarine Peninsula. Figure 1 shows it as a peninsula formed by an extension of the continental shelf (Soviet Bathymetric Chart, 1956)。

The nature of an ice floe, together with its slow rate of drift, make it an idealstable platform from which to make oceanographic observations. On Charlie this platform was used as a base to lower an underwater camera, bottom trawls and a piston corer. A six-foot square hole was chiselled by hand through a fifteen-foot hummock of old ice. An elevated hummock was chosen to prevent the hole from becoming inundated by summer melt water. A fifteen-foot tripod was erected to straddle the hole.

Work was seriously hampered by lack of a winch that did not arrive until September.A D-6 bulldozer was backed to the tripod and the towing winch on the rear of the machine used to hoist and lower equipment. The equipment was lowered on a 5/32" wire cable, fitted with a dynamometer attached to a fulcrum arm. The meter wheel sheave was suspended from the opposite end of the fulcrum.

One-hundred-ten photographs of the Arctic Ocean floor were taken in this manner. The underwater camera used was a model of the Ewing 
automatic camera designed by Dr. Edward Thorndike.

The most striking feature of the photographs taken atop the peninsula is the abundance and variety of marine life. (The author is indebted to Dr。Robert Menzies, formerly of Lamont, for identification of many of the biological species photographed and brought up in trawls). Ophiurids (starfish) are present in great numbers, predominating in most of the photos. Figure 5 shows three in an approximate area of one square meter. Two species of bryozoans (Fig。6), small fish, a shrimp (Sclerocrangor felox), jellyfish, holothurians, amphi pods, colonies of siliceous sponges (Fig. 6), and a sea anemone (Actiniarian) were photographed.

The amsunt of life is certainly due to shallow depths (258-398 meters). Two camera stations taken in a deep (2210-2260 meters) basin to the west of the peninsula show a general paucity of life, as would be expected in colder, darker water. Where life is photographed in deeper water, it is of a different variety. Starfish are conspicuously absent after appearing in all shallow photographs. The most outstanding form of life in deeper water, shown in Figure 8 is probably a crinoid. It much resembles a 3-4-foot long specimen dredged up by oceanographers of the University of Washington.

Underwater photographs taken from station Alpha (1957-58), in water of comparable depths (2200-2300 meters), also reveal a general paucity of life (Hunkins, 1960). However, the few deep creatures that 
were photographed resemble some of the shallow varieties in the station Charlie pictures. These include a bryozoan colony, an actiniarian and a cup-shaped sponge or colony of sponges (Fig。7)。 According to Timofeev (1957), Atlantic water $\left(0.4^{\circ} \mathrm{C}\right)$ flows over the top of the submarine peninsula (300-500 meters). This warmer water may aid the prime factor of light penetration in supporting the large shallow water population。

The same type bottom sediment is common to both shallow and deep photographs. All seventeen camera stations depict a fine mud, or lutite, type floor littered with pebbles (Fig。6), animal tracks, trails and imprints (Fig. 9) holes (Fig. 5) and, in the case of shallow depths, organic material. The most notable feature of the rock material is its uniform smallness $(<1 \mathrm{~cm})$, visible in all camera stations but one. The exception is a shallow station (258 meters), showing large $(6 \mathrm{~cm})$, angular rocks partly covered by sediment (Fig。8)。

The clay-size sediment appears the same as on photos taken from drifting station Alpha. It has been identified from trawls taken near both Alpha and Charlie camera stations as a dark brown lutite, containing a large percentage of foraminifera (Hunkins, 1959). Alpha photos also show an abundance of rocks, but of a more heterogeneous size range than those taken from Charlie. Rocks in both sets of photos are angular to subangular and exhibit no regular distribution pattern. This suggests rafting。 Charlie and Alpha rocks both are encrusted with organic matter. 
Sinuous, wandering tracks are a common feature of Charlie photos. At least two different types can be observed. Figure 9 shows narrow, straight tracks in the center part of the print; wider, discontinuous and more angular marks are visible in the top left portion. This picture was taken at 2260 meters.

It is thought that Figure 10, a shallow photo, will explain some of the narrow, sinuous trails by attributing them to the meanderings of starfish. The position of the animal, indicated by shadows, and the known angles of camera and flash, show its body held off the bottom by its arms. The attitude is one of walking. Visual inspection reveals each arm making a narrow trail in the soft sediment. The same type tracks are found in deep and shallow photos.

All the tracks are probably biogenic. They may also be due to animals like holothurians crawling along the bottom. Figure 10 also shows what is apparently a sea cucumber, or slug.

Pot holes, or hollows, are conspicuous in the photos of the ocean floor (Figs, 5, 11)。 The more angular, sharply outlined hole in Figure 5 is probably more recent than the equidimensional holes in Figure 11. An ophiuroid imprint at the right end of the depression in Figure 5 indicates it was not made by the camera „rigger weight. All the holes photographed have raised ridges around their circumference. Many irregular holes also appear in Alpha photos (Hunkins, 1960). The general angularity and irregularity of outline leads to the conclusion 
that they were formed by fallen rocks, rafted out by the ice.

Ripple marks do not appear in any of the photographs from station Charlie.

Five trawls were taken along the top of the submarine peninsula, one was taken in the basin to the west. The equipment consists of a three-meter long, cone-shaped net fastened to a $1 \times 3$ meter frame of soft iron. The opening was $10 \mathrm{~cm}$ high by one meter wide.

In the shallow trawls (269-422 meters) many of the animals photographed were brought to the surface. These include many starfish - as large as eight inches across and orange-red in color; a sea anemone; at least five species of Bryozoa, jellyfish and a few amphipods. A small fish, similar to those photographed, was retrieved and has been tentatively identified as a new species of Paralipapis. In addition, there were many polychaetes in the trawls.

The deep trawl, taken at 2225 meters, brought up amphipods, four species of isopods and copepods. A new species of benthic copepod is believed to have been found.

Organic detritus, consisting mostly of worm tubes, Bryozoa tests and mollusk shells, formed an appreciable percentage of all the trawled sediments. Mollusk shells were largely pelecypod uni-valves and fragments. Some complete bivalves, found intact, were opened but found to contain only sand and fossils. The mollusks that were identified are shallow water dwellers. All the shells and fragments exhibited excessive 
erosion and wear. These are additional facts substantiating rafting.

The polychaetes recovered and the tubes found in the sediments do not belong to the same species.

The number and variety of Bryozoans is noteworthy. Mohr, 1959, reports only one colony of well-eroded tests recovered by biologists working on T-3 from 1952-1955. It is not known whether the erect Bryozoans photographed belong to the same order as the tests (Cheilostomata and Cyclostomata) that were dredged. The photographed colonies, like some varieties of cheilostomes and the cyclostomes, are all branching, fern-like varieties of Bryozoa. Besides these, many ball-like accumulations of encrusting-type cheilostomes were recovered. Some of these accumulations measured $2.25 \mathrm{~cm}$ across. The calcareous tests are fragile and poorly cemented. It is not known if these are indigeneous or rafted.

The smallest fractions of sediments $(74 \mu-420 \mu)$ are rich in planktonic foraminifera. Only one species of planktonic foram is recognized, Globigerina pachyderma (Be, 1958). Nine species of benthic foraminifera were identified by Dr. Allan Bé, of which Cassidulina norcrossi and Cibicides species (?) formed the majority. Carbon containing contaminants were hand-picked from the sieved, $74 \mu-250 \mu$ fraction of sediments and the samples sent to the geochemistry laboratory at Lamont for radiocarbon dating. * *These were assigned an age of $5000 \pm 700$ years. 
One trawl sample, containing about 13 liters, has been sieved and separated into fractions. Clay-sized particles made up the largest percentage by weight and by volume. The smallest fraction examined, $74 \mu-250 \mu$, was composed of approximately $80 \%$ foram tests. Only $5 \%$ sand content is present as opposed to $15-56 \%$ sand found in the $0-5 \mathrm{~cm}$ layer of six cores taken from station Alpha (Menzies, 1958). The remaining $15 \%$ of the fraction was composed of organic detritus and manganese chips.

The coarser fractions consist of manganese coated limestones, light brown siltstones, brown sandstones, soft black shales and a small percentage of silica pebbles. Siltstones make up a high percentage of the 1.0-3.0 $\mathrm{mm}$ and 3.0-5.4 $\mathrm{mm}$ fraction. However, as size increases the - proportion of siltstones decreases, while the proportion of limestones increases. The relative proportion of sandstones to limestones remains fairly constant.

Sizes of rock specimens were, as photographed,' mostly smaller than $10 \mathrm{~mm}$. In a total of six trawls only 18 pebbles were recovered larger than $20 \mathrm{~mm}$. The largest rock was $80 \mathrm{~mm}$, and only two reached cobble size $(>64 \mathrm{~mm})$.

The fraction over $20 \mathrm{~mm}$ consisted of 13 limestones, 4 sandstones and 1 siltstone. The siltstone is a light brown, or tan, color, subangular, with a fragmentary coating of manganese and without encrustations. One sandstone is light brown, fine-grained and poorly cemented. It is $35 \mathrm{~mm}$ 
in size, coated with manganese and encrusted with worm tubes and Bryozoa tests. Two of the sandstone cobbles are dark brown and coarse grained. These are flat and angular in shape with coatings of manganese and indistinct organic matter. One sandstone is flat and angular, fine-grained, and the color of lignite (brown coal). Mica flakes are visible in all the sandstones.

Limestones range from a rounded, $25 \mathrm{~mm}$ pebble to a flat, angular, five-sided rock, $80 \mathrm{~mm}$ in size. This latter exhibits a line separating uncoated limestone from the manganese-coated, worm tube and barnacle encrusted portion. It is assumed that the uncoated portion was buried in the sediment, while the coated part was exposed.

Manganese coatings are generally very thin. One exception was a $20 \mathrm{~mm}$ pebble of limonite, or yellow siltstone, covered with a $1 \mathrm{~mm}$. thick coating.

A geode of manganese dioxide, $30 \mathrm{~mm}$ in size, was dredged from the top of the peninsula. It is similar to manganese nodules brought up from the floors of the Atlantic and Pacific.

No igneous or metamorphic rocks were found in a detailed visual examination of the sieved trawl, or in a cursory examination of the larger $(>20 \mathrm{~mm})$ rocks in the other trawls.

Rocks found in the trawls are very similar to those dredged up from station Alpha. In both cases limestones and sandstones predominate. Four dredges from Alpha yielded 55-75\% limestones and 5-25\% 
sandstones in the fraction $>7 \mathrm{~mm}$ (Hunkins, 1959)。 Six trawls from Charlie yielded $72 \%$ limestones and $22 \%$ sandstones in the fraction $>20 \mathrm{~mm}$. Charlie limestones are light-gray to brown-gray in color. Disseminated pyrite is visible in the $80 \mathrm{~mm}$ limestone cobble (browngray). Alpha limestones are described as light gray, blue-gray and yellow-gray; some pyrite crystals were found in a yellow-gray pebble (Schwarzacher, Hunkins, in press). Charlie sandstones vary from yellow to dark brown. One is made up of grains resembling lignite. Alpha sandstones also are described as varying from yellow to dark brown, with one of them containing bitumen (a coal-rock related to lignite).

The presence of large, angular pebbles on the floor of the Arctic Ocean is attributed to rafting by ice floes. Evidence for this has already been stated. Biological evidence for the rafting of shallow water mollusk shells has been cited earlier in this paper and is given by Schwarzacher and Hunkins。 The largest percentage of sediment from station Charlie trawls consists of clay-size particles. The large areas of blue-gray clay found on the ice floe where the station was located points to the fact that much clay is also rafted by the ice. Rafting, then, is an important source of Arctic Ocean sedimentation.

Many features of the $>20 \mathrm{~mm}$ pebbles point toward the conclusion that the source area is one of glacial till (ibid, in press). All but one pebble is angular or sub-angular. Some are faceted and four 
exhibit a characteristic flat, pentagonal shape. None of the se could have been submitted to extensive water transport. The poorly cemented and fragile sandstones (also the cheilostome accumulations) could not withstand beach erosion, or water transport. Finally, well-preserved glacial striae have been found on at least one limestone brought up in trawls from station Charlie.

Twenty cores were taken from the back of a D-6 bulldozer, using a small Ewing piston corer. This equipment has a $1-1 / 2$ inch diameter core barrel with a close-fitting brass piston. The head weighs 130 lbs. The high density and firm consistency of the bottom mud required an addition of 120 lbs. to obtain reasonably long cores. All cores were taken on the submarine peninsula, the longest measured 252 centimeters. These cores were taken in a plastic liner inserted in the core pipe. This was removed in its entirety, formaldehyde added and the liner sealed and shipped without the labor of extrusion.

Two features become immediately evident upon preliminary inspection of the cores. Most striking is the uniformity throughout most of the length. There is a notable absence of layering, most cores consisting essentially of uniform medium-brown clay. This indicates a constant source and unvarying conditions of deposition over a long period of time. It is in marked contrast to the stratigraphy found in Arctic cores taken from station Alpha. 
The second feature is a pronounced layer found at the top of most of the cores. This is a layer of dark brown foraminiferal lutite. It is the same as the sediment brought up in the trawls and is much darker and not as sandy as the layers below it. The layer is described from Alpha cores (Hunkins, 1959) and by Soviet translations (Whiting, 1956) as occurring in all of the Arctic cores taken and extending from 0-10 cm. The layer, however, is absent in some of the cores taken from station Charlie and where it does appear, it extends only to $6.5 \mathrm{~cm}$. This is a maximum; average thickness is more like $1.0-1.5 \mathrm{~cm}$. The bottom of this layer is more gradational than the sharp separation observed in Alpha cores.

Another layer consisting of yellow-brown clay is prominent in three of the cores. These were all taken in shallow water (282 meters) on the center of the peninsula $\left(164^{\circ} \mathrm{W}\right)$. The layer, from 4 to $17 \mathrm{~cm}$ thick, is located between 30 to 60 centimeters in the core. In two cases large $(>20 \mathrm{~mm})$, heavily coated $\left(\mathrm{M}_{\mathrm{n}} \mathrm{O}_{2}\right)$ limestone pebbles are located in this layer. The beds are not horizontal but exhibit a type of swirling or folding.

The only conclusion that can be drawn it that sedimentation processes on the submarine peninsula appear to differ from those in deeper water. More cores are needed from shelf areas to ascertain if this stratigraphy is, or is not, typical of shallow coastal areas in the Arctic. 
The seismic program was seriously hampered by non-delivery and late delivery of explosives. Daily reflection shots, to check the accuracy of the Precision Depth Recorder and to determine dip and strike, were not begun until August 17. The reflection "spread" consisted of twelve 14-cycle geophones, separated by a distance of 200 feet and arranged on the surface in an "L" shape. Explosives (usually one blasting cap) were placed at the junction of the two legs, just beneath the ice-water interface. Hydrophones placed at 50, 125, and 200-foot depths functioned as additional receivers.

Forty-one reflection shots were recorded between August 17 and October 5. Dips on top of the submarine peninsula varied from $4.5^{\circ}$ to $0.6^{\circ}$ and in the deeper basin to the west from $5.1^{\circ}$ to $0.0^{\circ}$.

During July and August, while awaiting explosives, shots fired from T-3 were recorded for sound propagation information. Threepound charges of C-3 were recorded over a distance of 600 miles. This unusual propagation is attributed to wave guide phenomenon caused by the steep velocity gradient in the Arctic Ocean. The velocity increases sharply with depth to an inflection point, then increases more slowly. Velocity in any layer, then, is less than in the layers below it. A concentration of energy results in the layers above the inflection point of the velocity curve. The uppermost layers act as a wave guide, or a type of half-Sofar channel, concentrating energy and creating strong dispersion。 
A long-period vertical seismometer was installed on the ice floe as an experiment to determine the feasibility of recording earthquakes from the pack ice. It appears that a seismometer station on floating ice is possible. At least one large earthquake, of magnitude 7.1 , was recorded. This shock originated in Wyoming-Montana on August 18, 1959 (Fig. 12). However, some 5-6 magnitude shocks occurring nearer the station and other 6-7 magnitude shocks further away were not observed. They may have been recorded, but are not distinguishable from high amplitude background due to oscillations of the ice. Background was the most difficult problem encountered.

The instrument was operated first at a seven-second period, then at ten seconds and finally at 40 seconds. An attempt was made to determine the natural, or predominant, periods of ice motion, and to filter them out electrically. The undesirable short periods were discriminated against by the use of four resistance-capacitance combinations in series. A 500,000 ohm coil was especially wound and installed on the seismometer pendulum. The electro-magnetically induced signal was fed into the filtering system, which was connected in series with an amplifier and recorder (Fig. 13). Capacitance was constant at a value of $50 \mu f$, period cut-off being controlled by resistance values. The signal was amplified by a sensitive volt-ammeter functioning as a D.C.amplifier。A pen and ink recorder operated in one-to-one correspondence with the amplifier. Time marks were made every minute from an accurate electric chronometer. 
The advantage of using this filter system is that only the desired longer periods are recorded even though the instrument may be set at a much shorter period. Ice tilt prevented setting the instrument at periods greater than 10 seconds, but the filter circuit was arranged to eliminate periods shorter than forty seconds. Cut-off is not sharp under these described conditions and periods from 20 seconds upward were recorded. The magnification of the instrument decreases as the period of the filter is increased.

Preliminary inspection of the records reveals a predominant frequency of 25-30 seconds. Spectrum analysis is necessary for more detailed investigation of these records。

The magnetics program measured both relative and absolute changes in the earth's field. Relative changes in the D, Z and $\mathrm{H}$ components were recorded continuously on film by a variograph. Absolute values were determined by the proton precession method.

In this method a polarizing current aligns hydrogen nuclei in a cono tainer of water. The current is shut off and the protons precess about the earth's field at a frequency characteristic of the total intensity. Pre. cession generates a signal which gradually dies due to proton collisions, differences in field strength from one part of the liquid to another, etc。 The signal registers on an electronic counter. The total cycle lasts six seconds, three seconds are devoted to polarization and three to precession. During freezing weather gasoline was substituted for water. Though 
essentially a prototype instrument, the nuclear precession magnetometer was in operation $90 \%$ of the time from June to October.

Records were made during a magnetic storm occurring 9-25 July。 During this disturbance the daily variation of magnetic intensity reached 600 gammas, as opposed to 300 gammas during normal times. Maximum variation during this storm was 1150 gammas. A solar flare occurring on 16 August produced an observed variation of 1650 gammas. The total field intensity is $57-58,000$ gammas。

An observed anomaly of 1350 gammas was recorded crossing the western edge of the submarine peninsula. Preliminary calculations of magnetic susceptibility suggest that the rock material of the elevation is ultra basic.

Future work in data reduction will include statistical and petrographic analysis of pebbles found in the trawls and cores. Detailed sampling and examination of strata and fossils in the cores will be carried out as well as a systematic examination of bottom photos. The results of seismic reflection and precision depth recorder records will be used as a basis for constructing a bathymetric map.

Magnetic records are being worked on at the present time. Spectrum analysis of vertical seismometer records is planned.

Long-range plans call for a continuation of the scientific program on the Arctic ice pack for a period of five years. The programs already outlined will be continued by Lamont personnel. Plans for expansion of 
the research include long-range refraction profiles to determine the character and origin of the Arctic Basin. A gravity program would be an important adjunct to seismology and magnetics, as well as being a possibility of determining Arctic Ocean tides. Air Force Cambridge Research Center has promised to supply a gravimeter. Since October Lamont has conducted an additional program in biology with emphasis on sampling of pelagic foraminifera at various depths. 
Bé, A. (1958) Biological aspects of Arctic deep-sea sedimentation; Section II, Final Report, AINA, Contract 47.

Browne, I. (1959) Ice drift in the Arctic Ocean; IGY Bulletin, No.24, National Academy of Sciences.

Hunkins, K. (1959) The floor of the Arctic Ocean; IGY Bulletin, No.22, National Academy of Sciences.

Hunkins, K., M. Ewing, B.C.Heezen, and R. J. Menzies (1960) Biological and geological observations on the first photographs of the Arctic deep-sea floor; Limnol。and Oceanog., v。 5, p. $154-161$.

Menzies, R。 (1958) Biological aspects of Arctic deep-sea sedimentation; Section I, Final Report, AINA, Contract 47.

Mohr, J. (1959) Marine biological work. An article in "Scientific Studies at Fletcher's Ice Island, T-3, 1952-1955'" Geophysical Research Paper No.63, para.93-101, GRD, AFCRC

Schwarzacher, W. and K. Hunkins (in press) Dredged gravels from the Central Arctic Ocean.

Whiting, K。 (1956) (Translation) Recent Soviet scientific investigations in the North Polar Regions; Documentary Research Division, Air University.

Worthington, L. V. (1953) Oceanographic results of project Skijump I and II in the Polar Sea, $1951-52$; Trans. Amer. Geophys. Union, - 34, p. 543-551.

Anon. (1957) Bathymetric chart of Arctic Ocean as of 1956 (approx.); Compiled for Defence Research Board of Canada, Ottawa. 


\section{List of Illustrations}

Figure $1 \quad$ Tracks of Drifting Station Charlie and Drifting Station Alpha

Figure $2 \quad$ Detailed track of Drifting Station Charlie

Figure 3 Bathymetric profile of the Chukchi Rise

Figure 4 PDR profile across the western slope of the Chukchi Rise.

Eigure 5 Bottom photograph taken on top of Chukchi Rise. Note Starfish and Jellyfish.

Figure 6 Bottom photograph on top of Chukchi Rise.

Figure 7 Bottom photograph in basin west of Chukchi Rise。 Note crinoid.

Figure $8 \quad$ Bottom photograph on Chukchi Rise。

Figure 9 Bottom photograph in basin west of Chukchi Rise。

Figure 10 Bottom photograph on the Chukchi Rise。

Figure 11 Bottom photograph on the Chukchi Rise。

Figure 12 Recording of Wyoming, Montana earthquake (August 18, 1959) at Station Charlie.

Figure 13 Circuit diagram for long-period seismograph. 


$\begin{array}{llll}\text { Fig. } & \begin{array}{c}\text { List of Photographs } \\ \text { Latitude }\end{array} & \begin{array}{c}\text { Longitude } \\ (\mathrm{N})\end{array} & \begin{array}{c}\text { Depth } \\ \text { (meters) }\end{array} \\ 5 & \begin{array}{l}77^{\circ} 41^{\prime} \\ 77^{\circ} 47^{\prime}\end{array} & 165^{\circ} 23^{\prime} & 265 \\ 6 & 77^{\circ} 42^{\prime} & 164^{\circ} 14^{\prime} & 258 \\ 7 & 77^{\circ} 43^{\prime} & 171^{\circ} 58^{\prime} & 2250 \\ 9 & 77^{\circ} 35^{\prime} & 172^{\circ} 00^{\prime} & 2200 \\ 10 & 77^{\circ} 42^{\prime} & 164^{\circ} 14^{\prime} & 258 \\ 11 & 77^{\circ} 50^{\prime} & 171^{\circ} 30^{\prime} & 2210\end{array}$




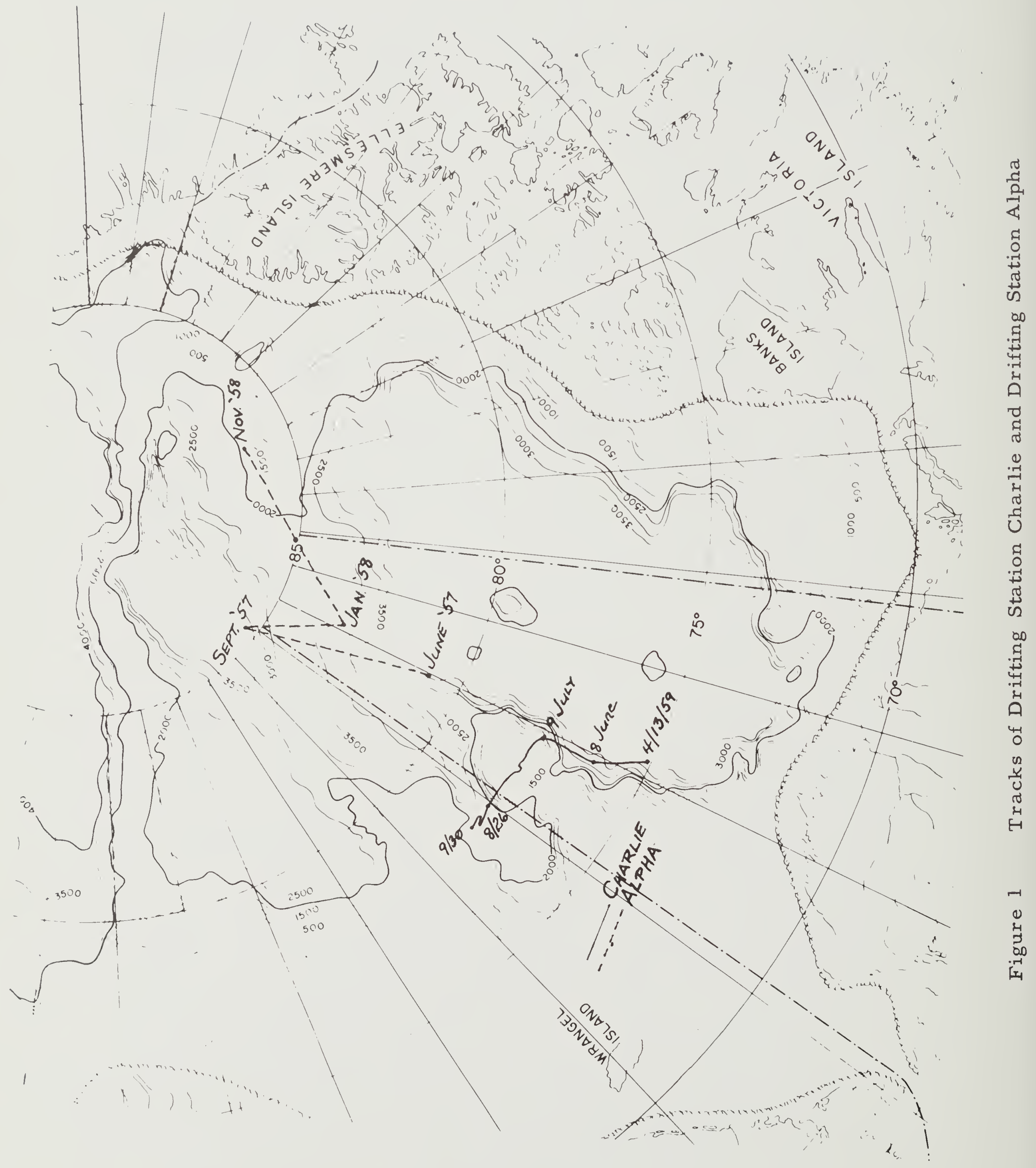




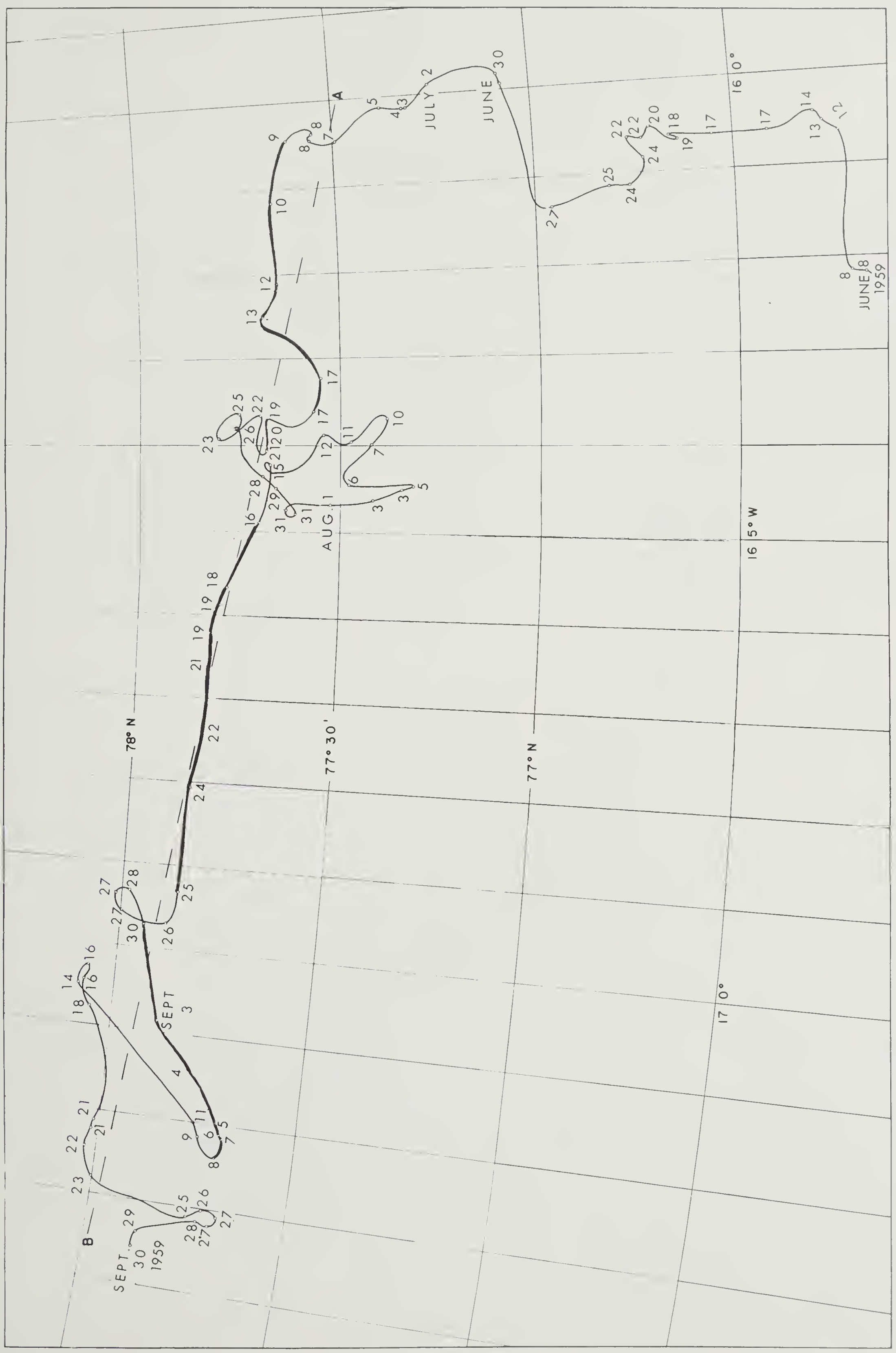



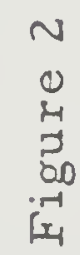




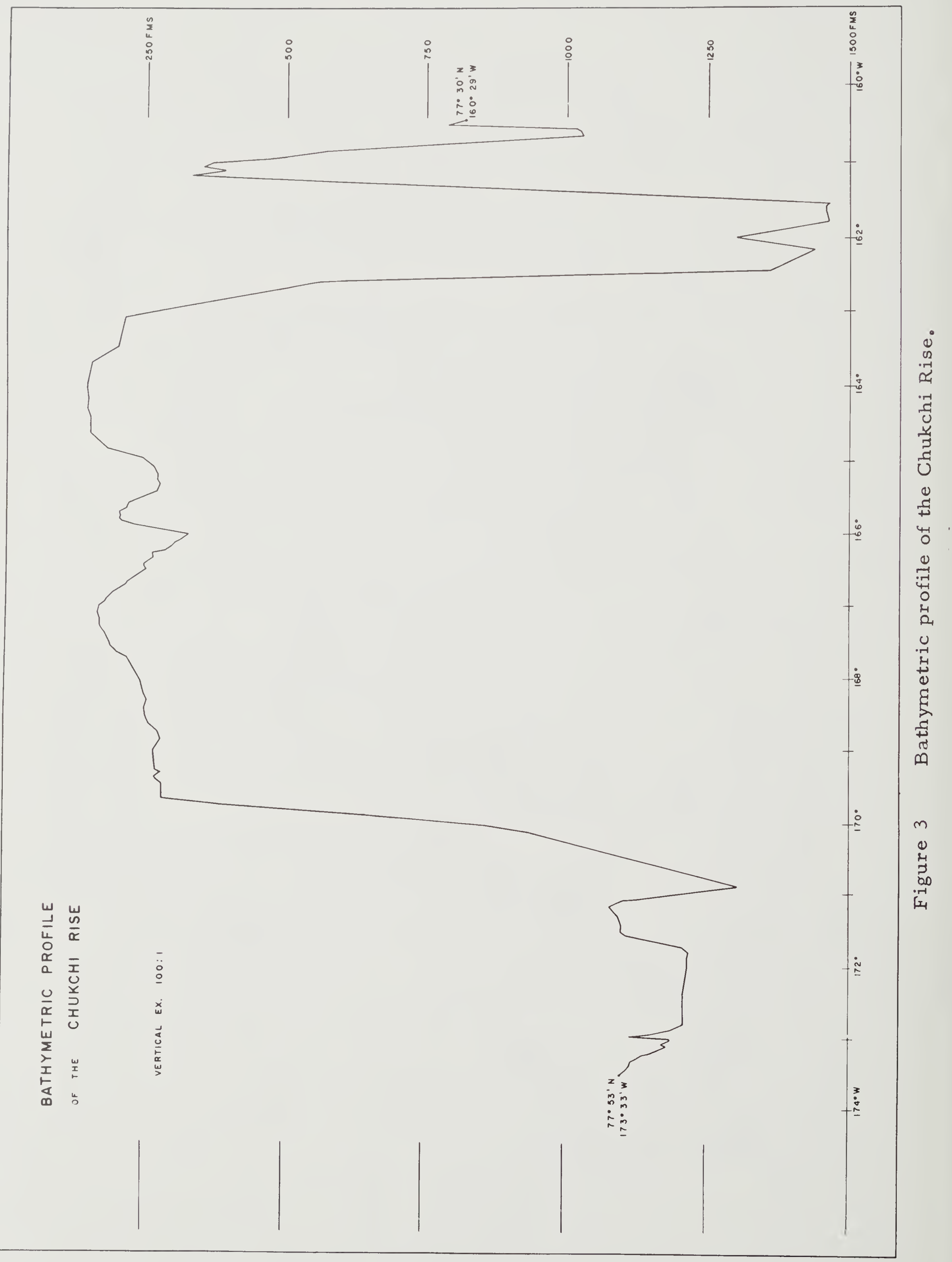



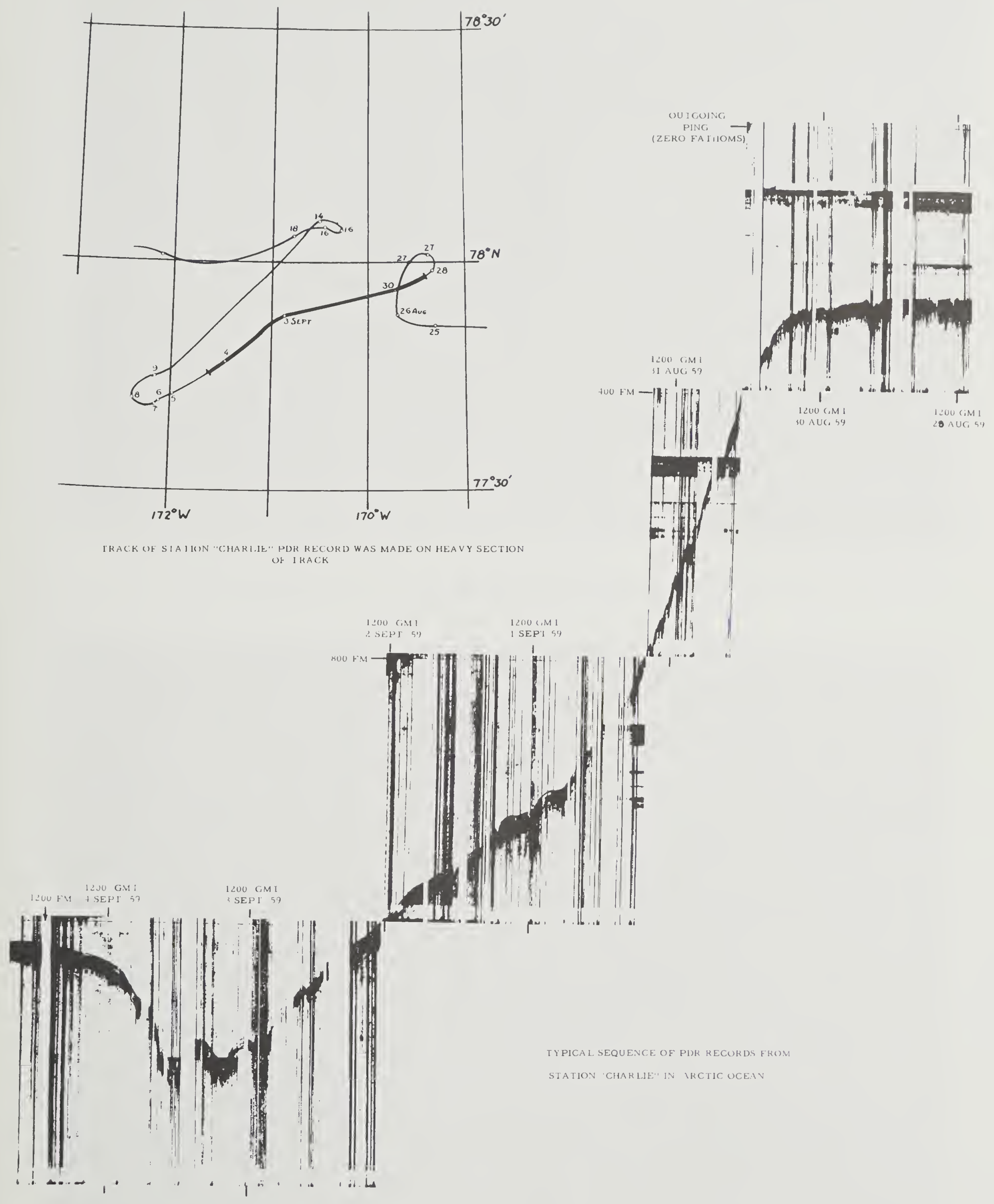

Figure 4 PDR profile across the western slope of the Chukchi Rise 


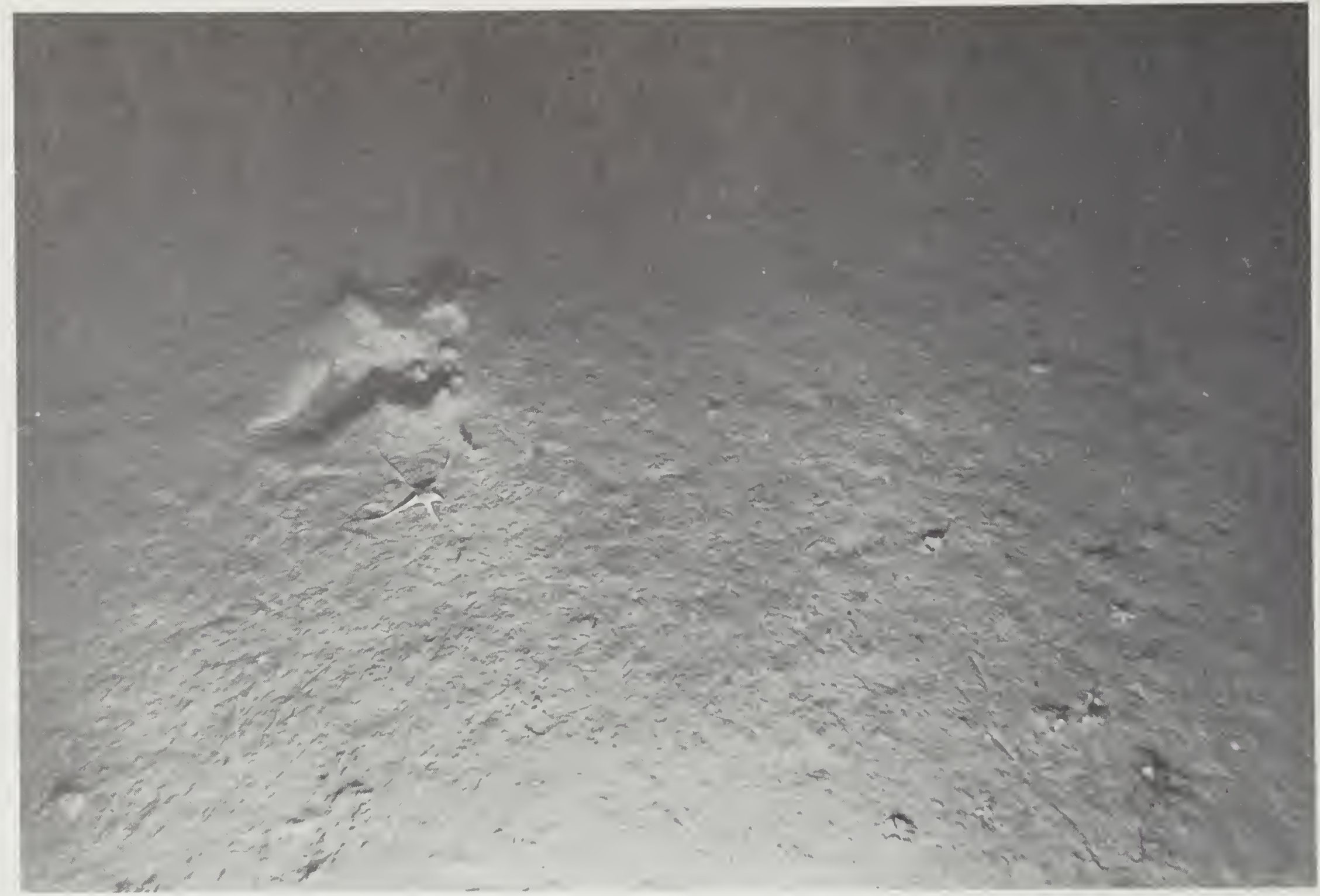

Figure 5 Bottom photograph taken on top of Chukchi Rise. Note Starfish and Jellyfish.

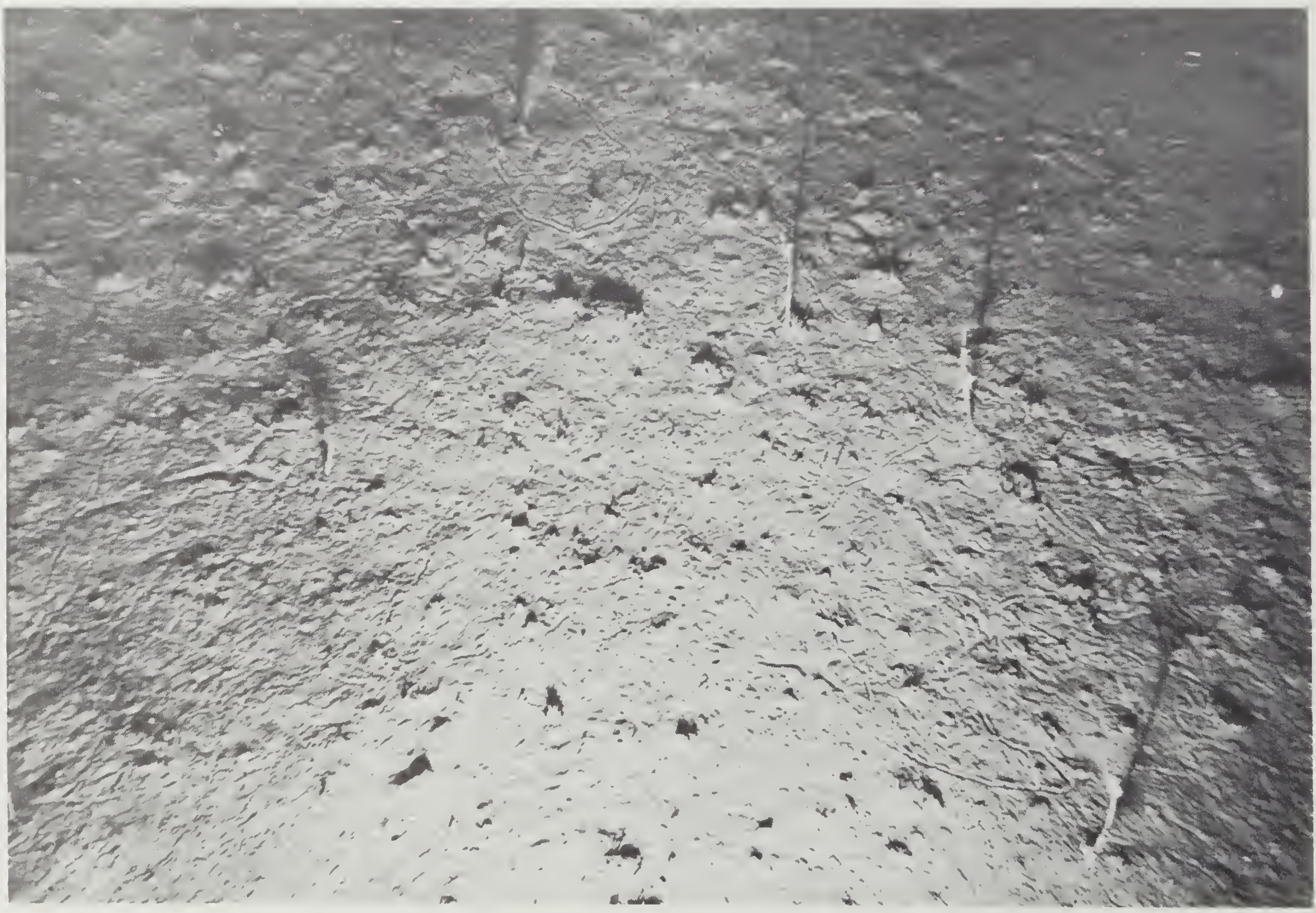

Figure $6 \quad$ Bottom photograph on top of Chukchi Rise. 


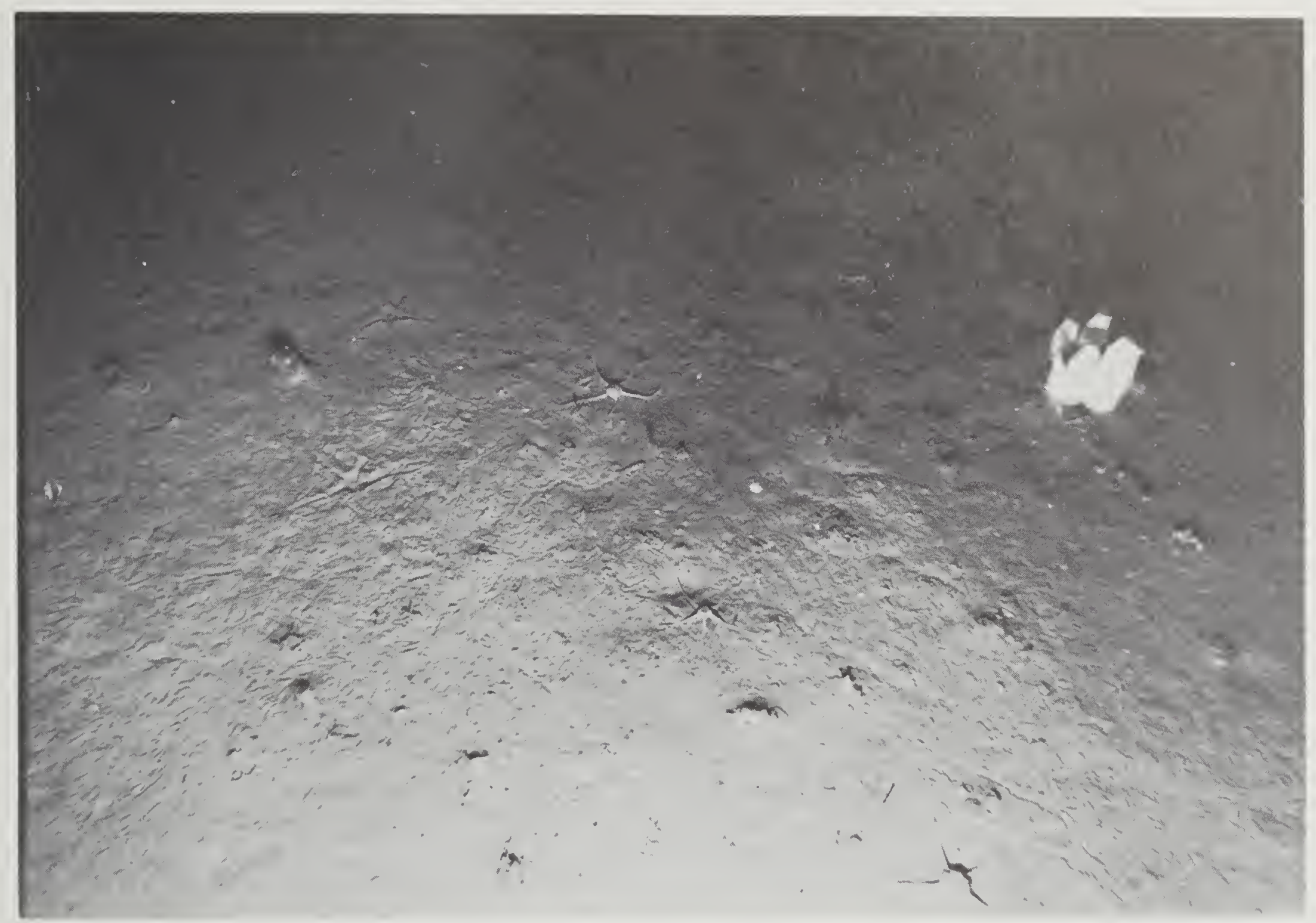

Figure 7 Bottom photograph on Chukchi Rise.

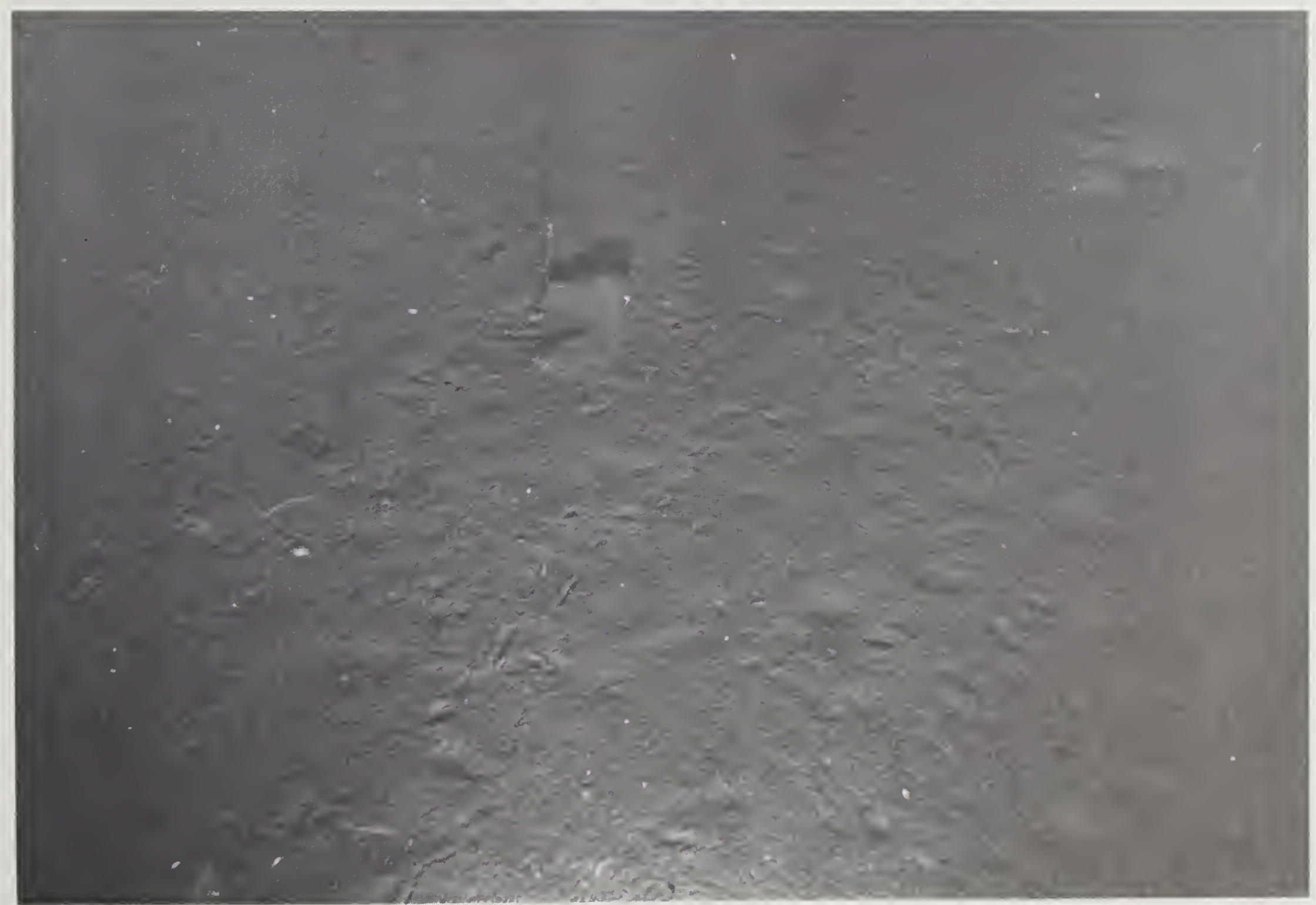

Figure 8 Bottom photograph in basin west of Chukchi Rise. Note crinoid. 


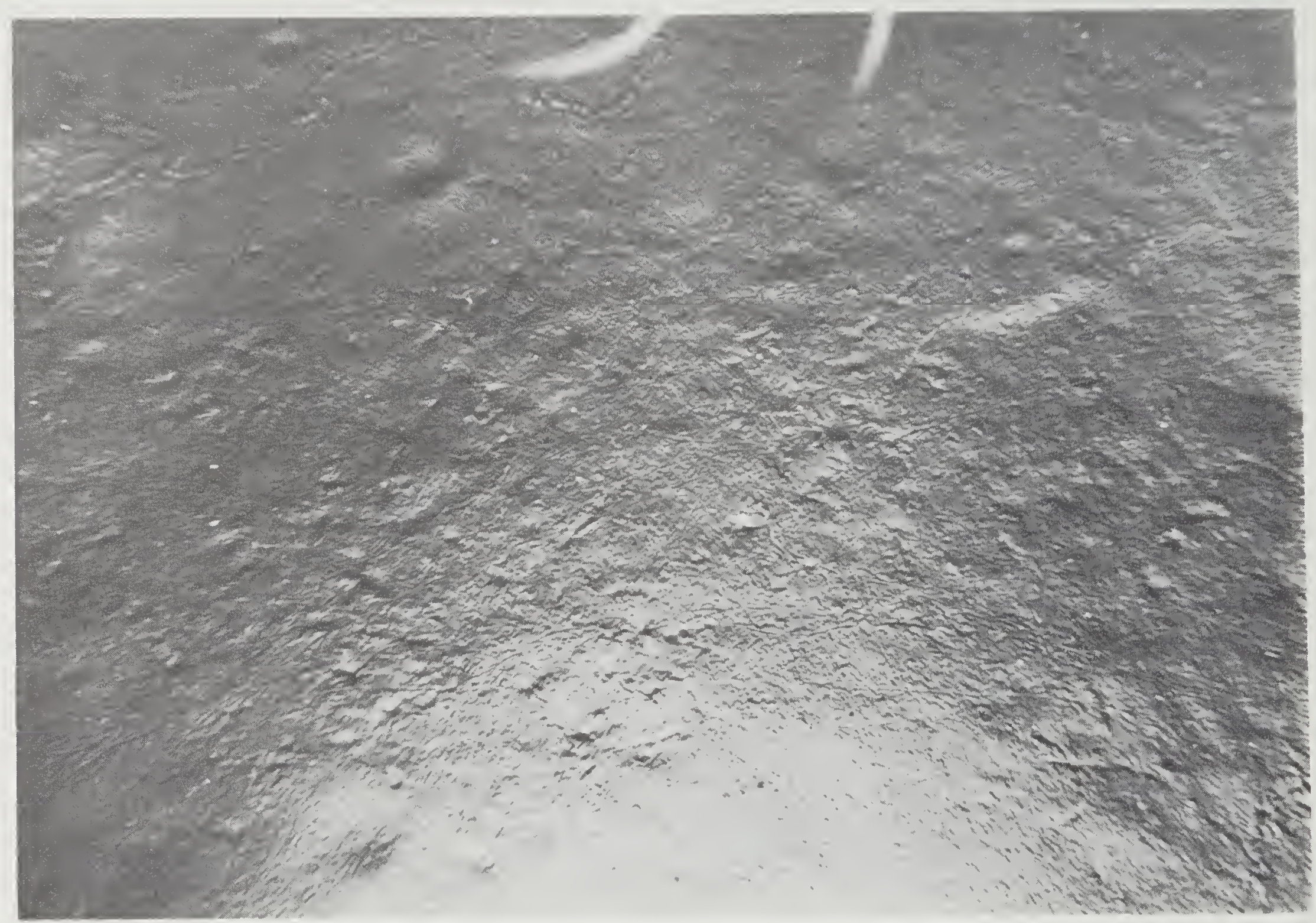

Figure 9 Gottom photograph in basin west of Chukchi Rise.

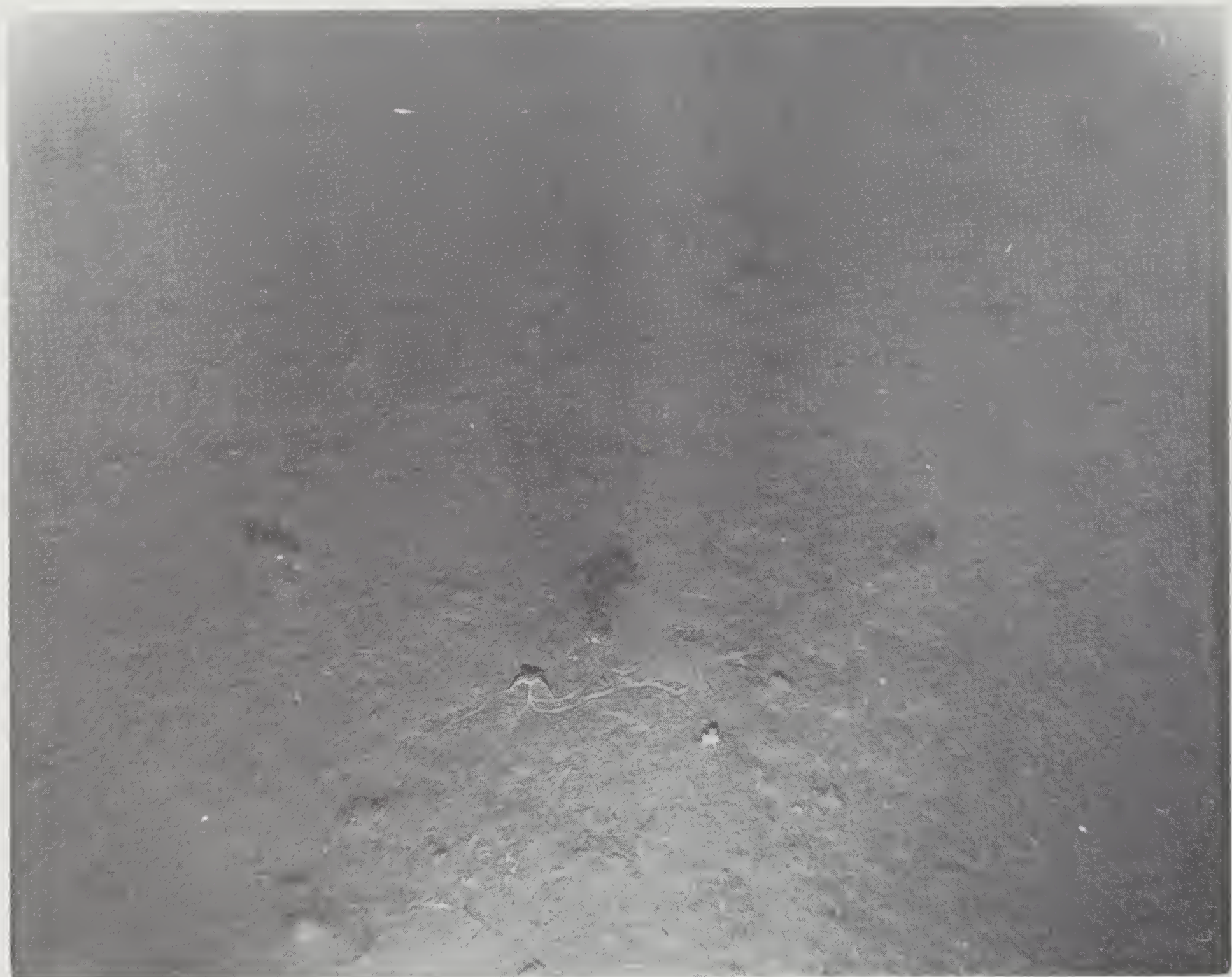

Figure 10 Bottom photograph on the Chukchi Rise. 


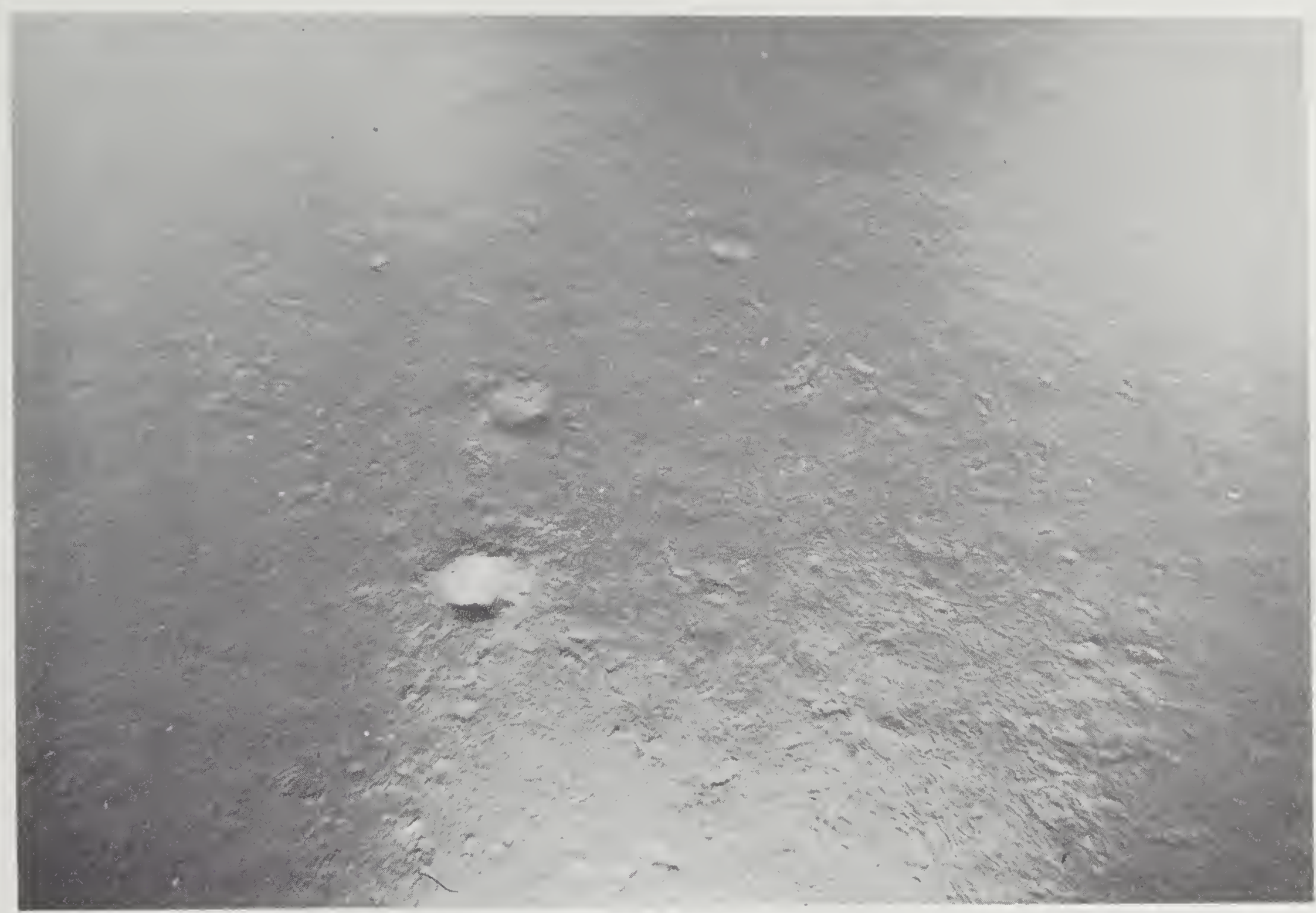

Figure 11 Bottom photograph on the Chukchi Rise. 


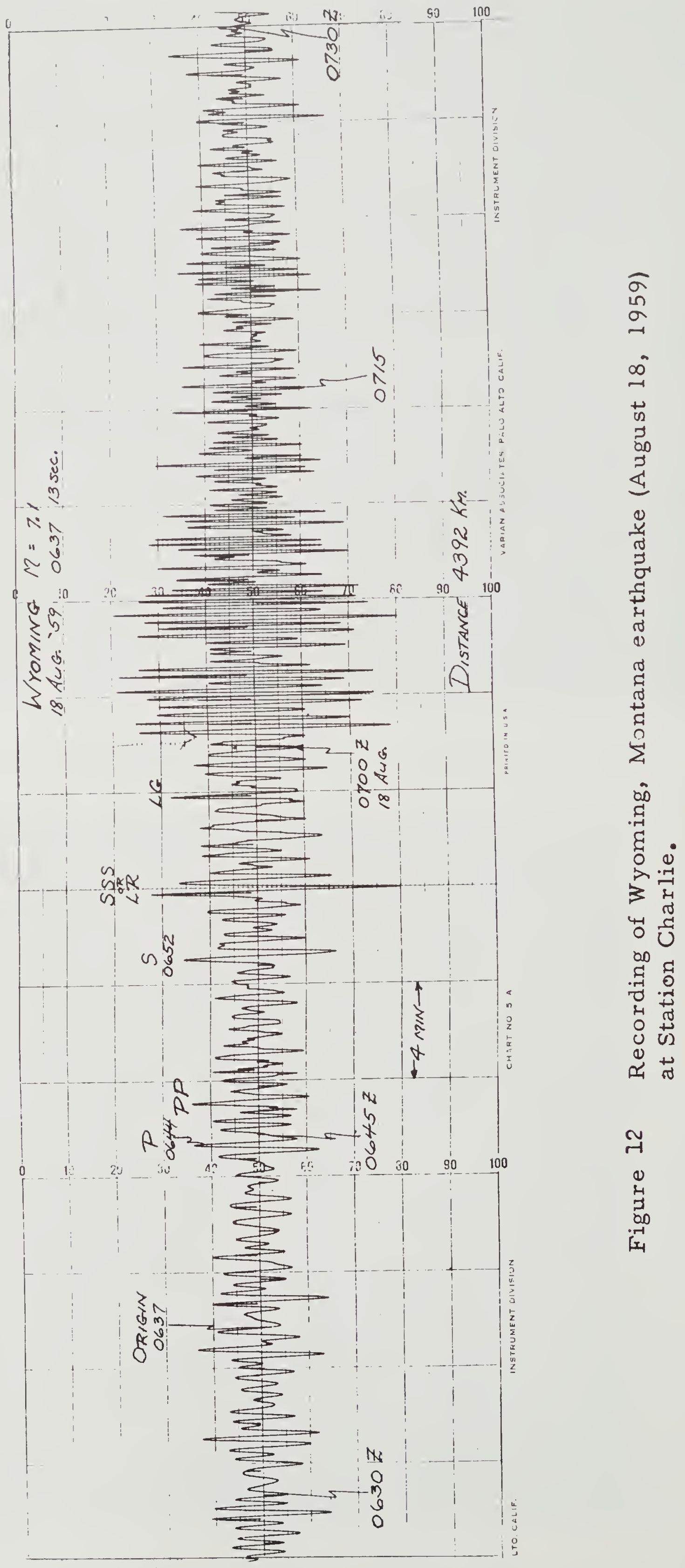




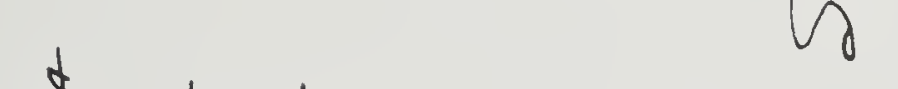

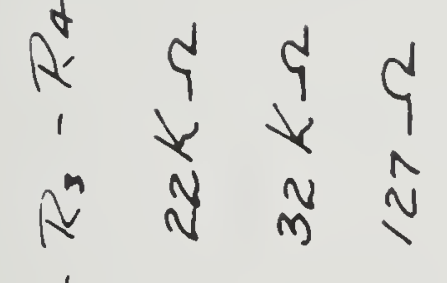

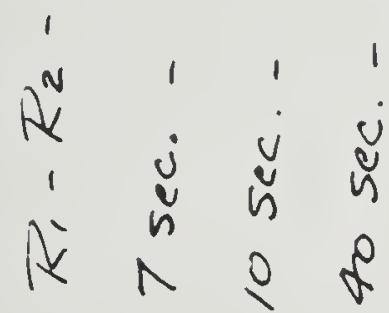

ドドド

京

4

u

U

j
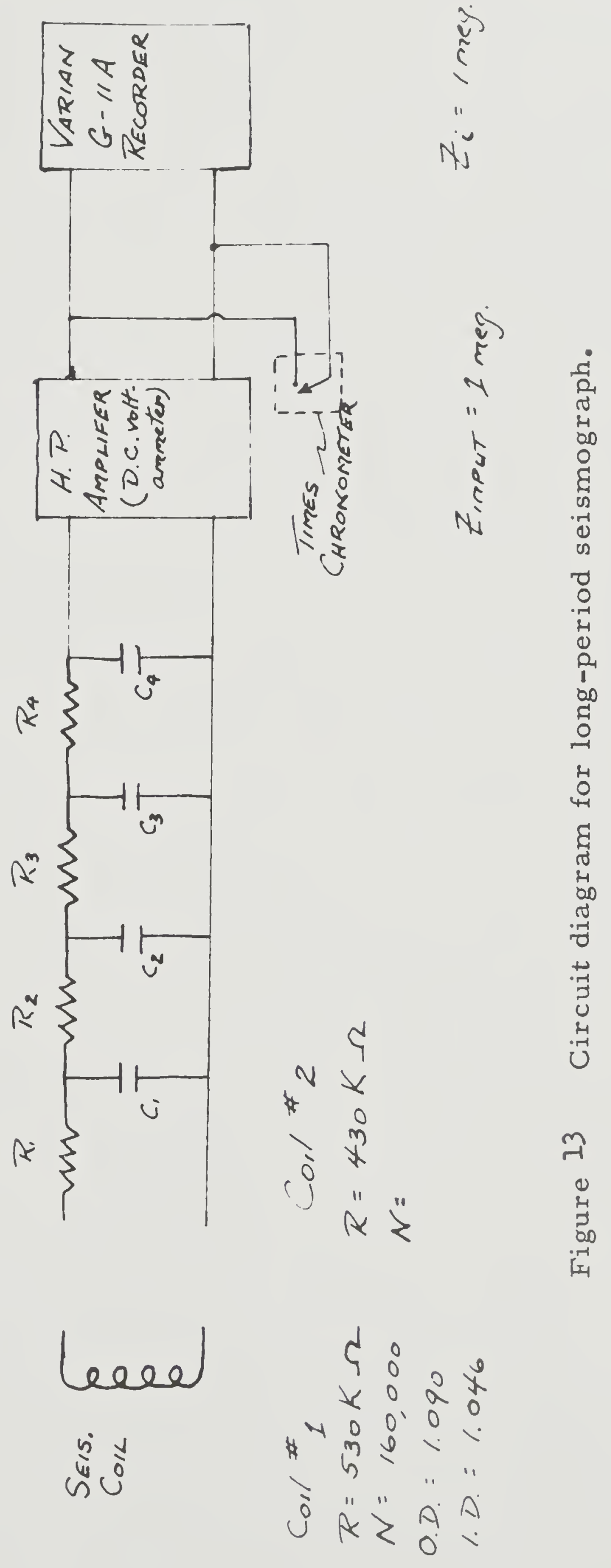

COLUMBIA LIBRARIES OFFSITE

|||||||||||||||||||||||||||||||||

$$
\text { CU90642180 }
$$


